\title{
A revised infrageneric classification and synopsis of the Afro-Eurasian genus Moraea (Iridaceae: Irideae)
}

\author{
P. GOLDBLATT ${ }^{1,3}$, J.C. MANNING ${ }^{2,3} \&$ J. SCHNITZLER ${ }^{4}$
}

Keywords: Iridaceae, Iridoideae, Moraea Mill., new species, southern Africa, taxonomy

\section{ABSTRACT}

Molecular phylogenetic studies of Moraea Mill. and the inclusion of Barnardiella Goldblatt, Galaxia Thunb., Gynandriris Parl., Hexaglottis Vent., Homeria Vent. and Roggeveldia Goldblatt in the genus have rendered the existing infrageneric classification, dating from 1976, in need of substantial revision. In particular, subg. Moraea and subg. Vieusseuxia have been shown to be paraphyletic. We propose a new infrageneric classification, based, as far as current data permit, on phylogenetic principles. Monophyletic subgenera and sections are circumscribed based on molecular phylogenies alone or in combination with morphological considerations. We recognize 11 subgenera, 15 sections and three series, arranged as follows in phylogenetic sequence: Plumarieae; Visciramosae (with sect. Multifoliae and sect. Visciramosae); Moraea (with sect. Moraea and sect. Polyphyllae); Galaxia (with ser. Unguiculatae, ser. Eurystigma and ser. Galaxia); Monocephalae; Acaules; Polyanthes (with sect. Serpentinae, sect. Deserticola, sect. Hexaglottis, sect. Gynandriris, sect. Polyanthes and sect. Pseudospicatae); Grandiflorae; Vieusseuxia (with sect. Integres, sect. Vieusseuxia and sect. Villosae); and Homeria (with sect. Stipanthera, sect. Flexuosae, sect. Homeria and sect. Conantherae). Most are moderately to well circumscribed at the morphological level either by floral or vegetative characters, except subg. Moraea, which includes a small number of unspecialized species apparently not linked by any apomorphic features. With over 27 new species described in the past 25 years and another 60 transferred to the genus, Moraea now includes 214 species. We provide a full taxonomic synopsis of the genus.

\section{INTRODUCTION}

Moraea Mill., the largest African genus of Iridaceae tribe Irideae, comprises \pm 220 species (214 recognized species plus several more yet to be described). Following revisions of its southern and tropical African members (Goldblatt 1973, 1976a, 1977b), Moraea was believed to be well understood and was considered to be monophyletic, largely on the basis of phenetic considerations and outgroup comparison. A close correlation between morphology and chromosome cytology in the genus, then including some 110 species, led Goldblatt (1976b) to propose an infrageneric classification that used cytology as a major determinant in circumscribing subgenera and sections. Later research in Moraea and related genera led to the realization that Moraea as so circumscribed was paraphyletic when Barnardiella Goldblatt, Galaxia Thunb., Gynandriris Parl., Hexaglottis Vent., Homeria Vent. and Roggeveldia Goldblatt were recognized. A phylogenetic study of Moraea based on DNA sequence data subsequently confirmed this conclusion, thus fully supporting its expanded circumscription (Goldblatt et al. 2002). This study and a second, more extensive one (Schnitzler et al. 2011) also showed that Goldblatt's 1976 infrageneric classification of Moraea required considerable revision if a classification follow-

${ }^{1}$ B.A. Krukoff Curator of African Botany, Missouri Botanical Garden, P.O. Box 299, St. Louis, Missouri 63166, USA. E-mail: peter.goldblatt@mobot.org.

${ }^{2}$ Compton Herbarium, South African National Biodiversity Institute, Private Bag X7, 7735 Claremont, Cape Town. E-mail: j.manning@ sanbi.org.za.

${ }^{3}$ Research Centre for Plant Growth and Development, School of Biological and Conservation Sciences, University of KwaZulu-Natal, Pietermaritzburg, Private Bag X01, Scottsville 3209, South Africa.

${ }^{4}$ Biodiversity and Climate Research Centre, Senckenberganlage 25, 60325 Frankfurt am Main, Germany / Institute for Ecology, Evolution and Diversity, Goethe University, Max-von-Laue-Str. 13, 60438 Frankfurt am Main, Germany; E-mail: jan.schnitzler@senckenberg.de MS. received: 2012-05-22. ing the principle of monophyly was to be implemented. In these molecular systematic studies some large species clusters comprised clades receiving moderate to strong support, but subg. Moraea included several disparate elements and required major restructuring to achieve a classification consistent with the phylogenetic principle of monophyly.

Some of the major changes include removal from subg. Vieusseuxia (D.Delaroche) Baker of sect. Polyanthes Goldblatt, which comprises a clade outside the subgenus and is sister to two lineages until now included in subg. Moraea. In addition, several individual species were shown by molecular, and sometimes cytological, data to be misplaced to subgenus or section. Re-evaluation of their morphology makes it clear that their position in the classification must be revised. This paper provides a new classification of Moraea based as far as possible on the principle of monophyly. Moraea now includes some 214 species, which we assign to 11 subgenera, 15 sections and three series. We also provide a full synopsis of the genus.

\section{MATERIALS AND METHODS}

Chromosome data for Moraea were obtained from studies by Goldblatt (1976a, 1976b) and later papers (most importantly Goldblatt 1981, 1986b, 1986c) and some chromosome counts not yet published (Goldblatt \& Manning 2013). Morphological information is from Goldblatt (1976a, 1976b, 1981, 1986a) and several later papers.

The molecular studies of Goldblatt et al. (2002) and Schnitzler et al. (2011) are summarized here and provide the framework for the revised classification. Some 161 species were included in the latter study, and three additional taxa have been sequenced for the present 
TABLE 1.-Additional Moraea species sequenced in this study with voucher information and GenBank/EMBL accession number for each gene region. Accession numbers for taxa not listed here can be found in Goldblatt et al. (2002) and Schnitzler et al. (2011).

\begin{tabular}{|c|c|c|c|c|}
\hline Species & Voucher & rbcL & rps16 & trnL-F \\
\hline Moraea intermedia Goldblatt \& J.C.Manning & Goldblatt, Manning \& Porter 13405 (NBG) & JQ846027 & JQ846024 & JQ846030 \\
\hline Moraea nubigena Goldblatt & Helme s.n. (NBG) & JQ846028 & JQ846025 & JQ846031 \\
\hline Moraea pearsonii Goldblatt \& J.C.Manning & Manning 3128 (NBG) & JQ846029 & JQ846026 & JQ846032 \\
\hline
\end{tabular}

study, over $75 \%$ of the genus (Table 1 ). PCR amplification and sequencing were performed as described in Goldblatt et al. (2002). Insertions/deletions (indels) were coded as present/absent following the 'simple indel coding' method of Simmons \& Ochoterena (2000), implemented in SeqState (Müller 2005). The final matrix comprised 3096 characters from three plastid markers (rbcL, rps16, and trnL-F) and 218 indels. Maximum parsimony analyses were performed using the heuristic search implemented in PAUP* (v. 4.0b10; Swofford 2002). Initial searches were carried out using 1000 replicates of random taxon addition and the tree bisection and reconnection (TBR) algorithm with equal character weights, retaining a maximum of 10 trees per replicate. The resulting trees were used as starting trees in a second search using the same parameters with a limit of 10000 trees, which were then used to reweight the characters according to the rescaled consistency index (RC). Successive searches were performed using the reweighted matrix until tree lengths reached stationarity. We performed 1000 bootstrap replicates using equal character weights and the TBR swapping algorithm, again keeping only 10 trees at each step. Maximum likelihood analyses were performed in RAxML (v. 7.2.1; Stamatakis 2006) using the BINGAMMA function, with the alignment divided into partitions according to gene regions. This process implements the $\mathrm{GTR}+\Gamma$ model for each gene with individual estimation and optimization of model parameters and a discrete morphological model as proposed by Lewis (2001) for the indels, which is comparable to the Jukes-Cantor model of nucleotide substitution. We performed 500 rapid bootstrap searches (Stamatakis et al. 2008), followed by a thorough ML search on the original alignment. Bayesian phylogenetic inference was performed using MrBayes (v.3.2.1; Huelsenbeck \& Ronquist 2001). The best-fit models of nucleotide evolution were implemented according to the Akaike Information Criterion (AIC) scores for substitution models evaluated using MrModeltest (v.2.3; Nylander 2004). For binary traits, MrBayes implements an F81-like model. Three independent runs with four chains each were run for 30000000 generations, sampling the Markov chain every 1000 generations. After removal of the first 3000000 generations as burn-in, all runs were combined to build the consensus tree. The alignment and consensus trees are available from TreeBase (accession number S13606).

\section{DISCUSSION}

All approaches resulted in highly congruent tree topologies. The phylogenetic tree presented here reflects the topology and branch length of the Maximum Likelihood analysis. Unless indicated otherwise, support values reported in the text (e.g. 1, 95, 92) represent Bayesian posterior probabilities (if higher than 0.5), and bootstrap support values from the Maximum Likelihood and Maximum Parsimony analyses (if higher than 50\%), respectively. Most of the major species clusters correspond to existing, named infrageneric taxa but their relationships to one another are often quite different from past interpretations of their affinities. Not entirely surprisingly, several species of uncertain affinity based on morphological considerations remain unresolved in the molecular analyses, notably $M$. cooperi, M. nubigena and $M$. papilionacea. The relationships of other species of which the affinities were uncertain, e.g. M. fergusoniae and $M$. radians, are established in the trees generated. Conversely, a few species appear in the molecular trees in positions unacceptable on morphological grounds, especially $M$. inclinata and $M$. rivulicola. These exceptions are discussed in more detail below in our proposed classification.

1. Subg. Plumariae: Moraea lugubris is linked with low significant statistical support $(\mathrm{pp}=0.55$, $67 \mathrm{BP}(\mathrm{MP})$ ) to the M. bubalina clade (Figure 1) in an association without morphological support. This taxonomically isolated species was retrieved as sister to all other species of Moraea in an earlier analysis (Goldblatt et al. 2002). M. lugubris is unique in Moraea in having coarsely netted corm tunics not matched elsewhere in Moraea, plumose style crests and stigmas located at the distal tips of the bifurcate style branches rather than as discrete lobes abaxial to the style branches. We recognize the monotypic subg. Plumariae for M. lugubris. Both the position of the stigmatic surfaces and the plumose style branches recall the genus Ferraria, which is well established as sister genus to Moraea (Goldblatt et al. 2002, 2008).

2. Subg. Visciramosae: the eight species of subg. Visciramosae (six included in the current phylogenetic analysis) are united by at least three morphological synapomorphies, notably sticky stems, unique brown, \pm woody, longitudually grooved corm tunics with a sticky secretion on the inner surfaces, and stigmatic lobes with a central forked tooth. The \pm free but closely contiguous filaments of some species of the alliance are also unique in Moraea, but might constitute an ancestral state (other Moraea species have filaments partially or completely united except in some species of the very derived M. tripetala complex and in M. thomasiae, both subg. Vieusseuxia). Ferraria, sister genus to Moraea, has partially united filaments in all species. Floral mor- 
phology is unremarkable in subg. Visciramosae except in the species with free filaments and in those with the style branches reduced and lacking crests and the inner tepals as well as the outer with nectar guides (a derived condition that recurs in several other clades). M. simplex stands out here in having filiform style branches extending between the stamens, a condition shared by the unrelated M. fistulosa and M. monticola (assigned here to sect. Pseudospicatae of subg. Polyanthes, although neither was included in the molecular analysis).

The members of subg. Visciramosae comprise two separate, well supported (both $\mathrm{pp}=1$ and $>90 \mathrm{BP}$ ) clades (Figure 1). One, including the multi-leaved Moraea bubalina and M. vespertina, is weakly linked with $M$. lugubris and the other, including the remaining species, which are characterized by presence of two foliage leaves, is placed as sister to the rest of the genus with only moderate support. The clear morphological synapomorphies that the two clades share (sticky stems, sigmoid branching, unique corm type, stigmatic appendages) provide adequate justification for ignoring the weak molecular data in treating both lineages within a single subg. Visciramosa. We recognize the two lineages as separate sections, Multifoliae and Visciramosae.

3. Subg. Umbellatae: M. longiflora (sect. Tubiflora Goldblatt), plus several species from sect. Moraea ( $M$. intermedia, $M$. margaretae, $M$. nana and $M$. umbellata) were retrieved as a well-supported clade (1, 99, 96; Figure 1) sister to M. maximiliani. The second member of sect. Tubiflora, M. cooperi, was retrieved in an isolated but only weakly supported / unsupported (4-14 BP) position (Figure 1). We find it most unlikely that the molecular topology reflects the true relationships of $M$. cooperi as the morphological evidence linking it to the M. intermedia clade (i.e. subg. Umbellatae) is strong. Unique brown corm tunics, woody with plane surface (without the sticky secretion on the brown, longitudinally grooved corm tunics of subg. Visciramosa), darkly veined, pale yellow tepals, blunt outer inflorescence spathes usually not sheathing distally, and flowers with a perianth tube are all evidently derived character states that are shared with $M$. longiflora of the subgenus. Those features in $M$. cooperi may be homoplasious, but it seems to us unlikely that the entire set could have evolved independently. Thus we prefer to place $M$. cooperi in subg. Umbellatae rather than recognize it as a separate genus with the same morphological circumscription as subg. Umbellatae. We include eight species in what we designate subg. Umbellatae (one species, $M$. linderi, was not included in the molecular analysis). We note that $M$. maximiliani was retrieved as sister to the remaining members of the subg. Umbellatae clade and its position is weakly supported; nevertheless, it has the morphological synapomorphies of the subgenus hence its inclusion therein. We see no need for its recognition as a separate, monospecific subgenus or section in light of the morphology.

Floral diversification in the subgenus parallels that in subg. Visciramosae, ranging from an unspecialized Moraea-type flower with well developed style branches and crests and larger outer tepals bearing nectar guides, to reduced style branches lacking crests $(M$. maximiliani, M. umbellata) and, in M. nana, to style branches represented by paired, filiform arms extending on either side of the opposed stamen. The flower type in $M$. nana is convergent with that in the Hexaglottis group (subg. Polyanthes sect. Hexaglottis), in M. hexaglottis (not sequenced) and in M. pearsonii (now subg. Polyanthes sect. Pseudospicatae).

4. Subg. Moraea: here much reduced in size, includes $M$. vegeta, type of the genus, plus $M$. gawleri and its close relative, $M$. vlokii, which together form a well-supported clade $(1,100,99)$. The phylogenetic position of this clade (sister to the first polytomy in the tree) was, however, not supported in the bootstrap analyses and thus remains uncertain. To this small alliance we provisionally add $M$. namaquamontana and $M$. indecora, a rare Namaqualand endemic, and not yet sequenced.

Moraea garipensis and $M$. ramosissima constitute another small clade $(1,100,100)$ included by Goldblatt (1976b, 1986a) in subg. Moraea. A separate subgenus for the two species seems unwarranted as the molecular topology here is not well supported and we therefore provisionally retain them as a section of subg. Moraea pending additional molecular studies. At the morphological level, the species of subg. Moraea share palecoloured corm tunics, mostly of fine fibres, except for $M$. garipensis and M. ramosissima. Further molecular analysis may show an alternative placement for these two species, the brown corm tunics of which recall those of subg. Umbellatae.

The rare Western Cape mountain endemic Moraea nubigena appears as isolated in the molecular phylogeny (Figure 1) as it does morphologically. The acaulescent habit, solitary leaf and unbranched stem are all distinctive but may be adaptations to its montane habit. Goldblatt (1986a) linked the species to M. lugubris, but that now seems unlikely. $M$. nubigena has a chromosome number of $n=10$ and a fugaceous flower, both plesiomorphic in Moraea, and finely fibrous corm tunics, evidently an apomorphy for subg. Moraea but the blue perianth is otherwise unknown in the subgenus. We provisionally include it in subg. Moraea, with which the corm tunics are consistent, but it is not referred to any section. We note that it is the only blue-flowered and single-leaved member of the group. An argument can be made for the alternative, a separate subgenus for $M$. nubigena, but we see no value in a monospecific subgenus for the species.

5. Subg. Monocephalae: the lineage including Moraea angusta and two immediately related species is moderately well-supported $(1,89,65)$ as one of a polytomy (Figure 1). The alliance (including M. vallisavium, not sequenced) is united by unbranched stems, a single foliage leaf inserted well above ground level, a terete leaf blade, obtuse to truncate inflorescence spathes, sticky nodes, a prismatic ovary, and flattened, discoid seeds. The alliance was treated as the rank-less group Monocephalae by Baker (1896, then including $M$. spathulata of subg. Grandiflora), and as subg. Monocephalae by Goldblatt (1976b). Although M. namaquamontana is retrieved as sister to the $M$. angusta clade in all molecular analyses, this association is without statistical or morphological support and there is little reason to doubt that $M$. namaquamontana is allied to 


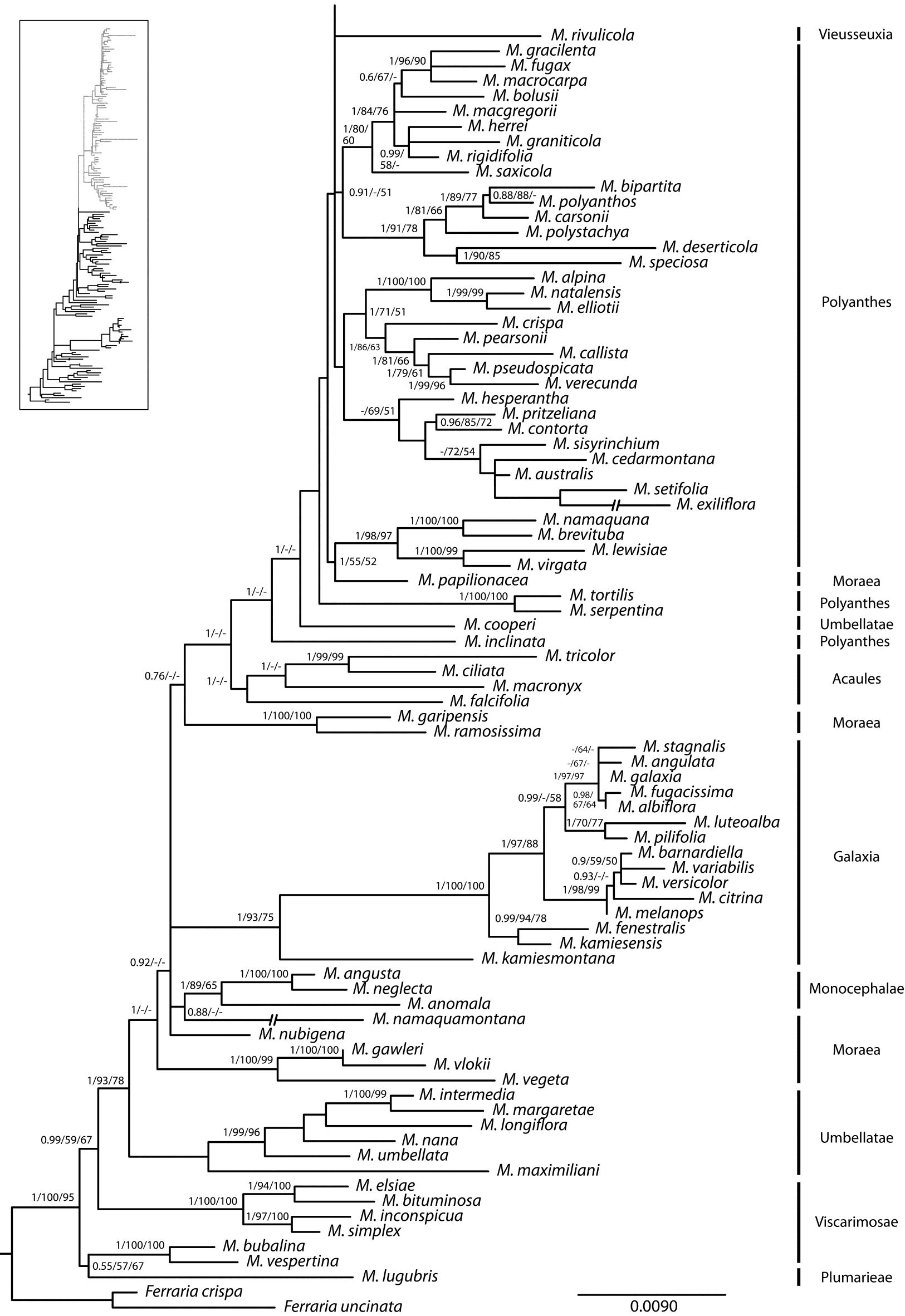

FIGURE 1.-Maximum Likelihood phylogeny of Moraea. Support values at nodes are Bayesian posterior probabilities, and bootstrap values from the Maximum Likelihood and Maximum Parsimony analyses respectively if $\mathrm{pp}>0.5$, or BS $>50 \%$. The subgeneric classification is indicated by black bars on the right. 


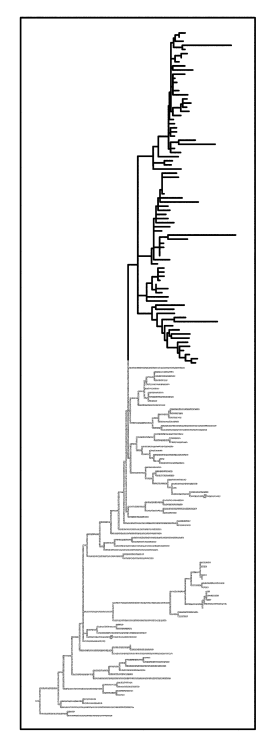

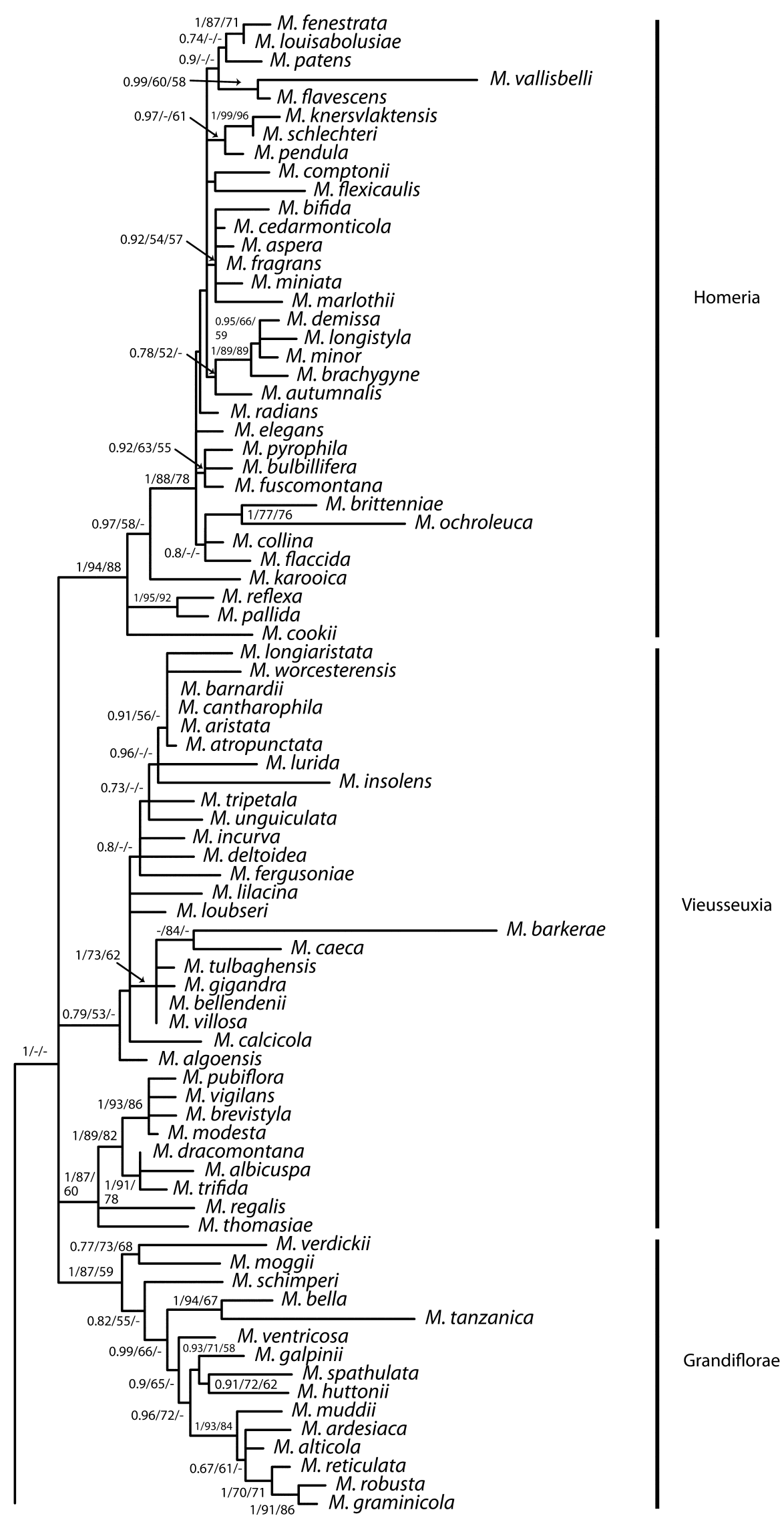


M. gawleri (subg. Moraea), with which it shares a virtually identical flower, a distinctive, asymmetric corm, and globose capsules. The $M$. angusta alliance is phylogenetically isolated and well defined by several morphological synapomorphies, and we continue to accord it subgeneric rank.

6. Subg. Galaxia: all species previously treated as the genus Galaxia (Goldblatt 1984a) comprise a well-supported $(1,93,75)$ clade. The alliance has several synapomorphies, not least an acaulescent habit, flowers always with a perianth tube, style branches short and lacking crests, and an asymmetric corm, and we recognize it as subg. Galaxia. Relationships within subg. Galaxia are more complex than reflected in Goldblatt's (1979b) recognition of two sections. Although sect. Eurystigma (species with entire style branches) is retrieved as monophyletic, sect. Galaxia (species with fringed style branches) is shown to comprise two lineages, the $M$. galaxia clade and M. kamiesensis plus M. fenestralis. A strictly phylogenetic classification would thus require the recognition of three or four sections, but we do not feel that this is justified in such a small group and suggest that the level of series is adequate. The position of the isolated M. kamiesmontana in the tree (Figure 1) as sister to the remaining members of the clade has morphological support; it is the only member of the subgenus that has clawed tepals, the plesiomorphic condition in Moraea. We thus admit three series, Eurystigma, Galaxia and Unguiculatae, this last monospecific.

7. Subg. Acaules: the species of the taxonomically isolated Moraea ciliata group were retrieved with strong support in the Bayesian analysis $(p p=1)$ as sister to the remaining species of Moraea and we accord the group subgeneric status. Within the group $M$. ciliata, $M$. macronyx and $M$. tricolor are obviously closely related, with the morphologically somewhat different $M$. falcifolia as sister. One more species belongs here, M. longipes, until recently included in $M$. ciliata (Goldblatt \& Manning 2009). Synapomorphies for subg. Acaules include leaves clustered at the terminal node, stem usually below ground level at flowering time (not M. longipes), sessile flowers raised above the leaves and inflorescence spathes on an elongating, tubular stalk; possibly the sterile base of the ovary (called a contractile pedicel in older literature) that retracts after flowering. The alliance was treated as sect. Acaules by Goldblatt (1976b), following Baker (1896).

8. Subg. Polyanthes: the Moraea serpentina-M. tortilis species pair $(1,100,100)$ is weakly placed as sister to the remaining species in the genus, but without statistical support. On morphological grounds, we include the six main clades (Figure 1) of this large group, including $M$. serpentine- $M$. tortilis, as sections of subg. Polyanthes. The alliance is united morphologically by distinctive blackish, wiry corm tunic fibres, but the multi-leaved habit (reduced in some species to a single leaf) and fugaceous flower are plesiomorphic. We note that, in addition, many species of the subgenus have an apomorphic, included ovary, but the condition is reversed in two sections. The subgenus is mixed for chromosome number: a base number of $x=20$ is ancestral and basic for two sections, Serpentinae and Deserticola (but reduction to $x=6$ (or 5) has occurred within sect. Deserticola) and $x=6$ is almost exclusive in sect. Hexaglottis, sect. Gynandriris, sect. Polyanthes and sect. Pseudospicatae (one species of sect. Polyanthes, M. inclinata has $n=6$ and 11).

In the molecular analyses, Moraea rivulicola is retrieved in an unresolved polytomy in subg. Polyanthes, but without any statistical support. This species has all the morphological hallmarks of subg. Vieusseuxia as we noted in an earlier molecular analysis (Goldblatt et al. 2002) and sequences of a second and third sample of the species alters this topology hardly at all, ruling out experimental error. Another species that appears misplaced here on morphological grounds is M. exiliflora, which almost certainly belongs in sect. Polyanthes according to morphology. We have no explanation for the apparently anomalous position of these two species in our trees, but to suggest that their morphology is somehow convergent with those clades to which morphology suggest they belong, is unacceptable. The remaining species of the clade, which comprise sect. Gynandriris (Goldblatt 1998), and originally the genus Gynandriris (Goldblatt 1980b), have apomorphic, translucent inflorescence spathes and a sessile ovary with a tubular, sterile beak, which leaves no doubt that it is a monophyletic alliance. The clade receives moderate support in the molecular analyses (69 and $51 \mathrm{BP}$, respectively; $\mathrm{pp}=0.6$, but excluding $M$. exiliflora). Two species of sect. Gynandriris, M. sisyrinchium and $M$. mediterranea (=G. monophylla Boiss. \& Heldr. ex Klatt and not sequenced), occur in the Mediterranean Basin and Middle East and constitute the only species of Moraea that occur north of the Sahara.

Sect. Hexaglottis [the genus Hexaglottis sensu Lewis (1959) and Goldblatt (1987)] has the derived, Hexaglottis-type flower with subequal, spreading tepals with short claws and style branches reduced to filiform arms extended on either side of the opposed stamen. The inclusion of M. papilionacea in the clade (Figure 1) receives only weak support in the bootstrap analyses (55 and $42 \mathrm{BP}$, respectively) and has no morphological basis, but the affinities of this species are uncertain and we prefer to retain it as unplaced in subg. Moraea, to which it was assigned by Goldblatt (1976b, 1986a).

Sect. Pseudospicatae $(1,71,51)$, sect. Deserticola $(1,80,60)$ and sect. Polyanthes $(1,91,78)$ are retrieved as monophyletic in the molecular analysis and are also morphologically coherent. The members of sect. Polyanthes sensu Goldblatt (1976b, 1986a) fall in two lineages; the first (here sect. Polyanthes) mostly with multiple leaves and the second (sect. Pseudospicatae) with a single leaf. Both clades include species with typical Moraea-type flowers as well as others with reduced style branches and style crests. We include $M$. inclinata in sect. Pseudospicatae without hesitation, despite its anomalous position in the tree, sister to $M$. cooperi plus the rest of the genus. It has a single leaf, blue flower, exserted ovary and capsule, and basic chromosome number of $x=6$, all of which accord with this decision. It is allied to, and sometimes has been included in, M. natalensis of sect. Pseudospicatae. Although sect. Deserticola (unranked Subracemosae Baker) likewise has species with the typical Moraea flower and others with reduced style branches and crests (the $M$. rigidi- 
folia-M. herrei clade, BP 54), all members consistently have the ovary included in the spathes. The ovary is sessile in $M$. herrei and has a sterile beak, also present in a less developed state in $M$. rigidifolia and the M. fugax group $(1,96,90)$. Sect. Deserticola closely resembles sect. Serpentinae in several morphological features and we would not be surprised if additional molecular data show them to be a clade. The available molecular data, however, preclude their union.

Subg. Polyanthes is sister to a polytomy formed by four large clades that include the remaining species in the genus. Two of these coincide exactly with subg. Grandiflora sensu Goldblatt (1976b) and subg. Homeria sensu Goldblatt (1981); and we continue to treat them as subgenera rather than sections because of their large size.

9. Subg. Grandiflorae: this subgenus (1, 87, 59) includes some 28 species of eastern, southern and tropical Africa. Most are tall, have unbranched stems and large, evidently unspecialized flowers that are long-lived in almost all species. All have a solitary leaf, distinctive, flattened, discoid seeds and a karyotype of large, subacrocentric chromosomes with a base number of $x=6$. With only half its species sequenced for the molecular study, subg. Grandiflora is still inadequately sampled and no clear morphological patterns are evident in the tree topology.

10. Subg. Vieusseuxia: we treat the remaining two clades as constituting subg. Vieusseuxia, which has until now included sect. Vieusseuxia of Goldblatt (1976b) plus the monospecific sect. Integres. All species share a basic chromosome number of $x=6$, but often a somewhat variable karyotype, although always of relatively large chromosomes. Members of the subgenus have derived, long-lived flowers (a fugaceous flower is plesiomorphic in Moraea), a single foliage leaf, also derived (multiple leaves only in M. fergusoniae must be interpreted as a striking reversal), and inner tepals that are typically much reduced, often 3-lobed or even absent.

There is no morphological support for the two separate clades $(1,87,60$ and $0.79,53$, respectively; Figure $1)$, and there are few obvious subclades in subg. Vieusseuxia that correlate with morphological patterns. A separate analysis of the alliance including additional molecular markers is probably needed to better resolve the phylogeny.

Moraea fergusoniae (included in subg. Moraea by Goldblatt 1976b) is inconsistent in subg. Vieusseuxia in its several leaves, but is shown to be nested in the subgenus, where its basic chromosome number, $x=6$, and trilobed inner tepals accord perfectly. We include it here without hesitation. The Cape species, M. thomasiae, separated by Goldblatt (1986a) as sect. Integres on account of its entire inner tepals, yellow flowers (rare in the subgenus) and \pm free stamens, is morphologically isolated in subg. Vieusseuxia and we continue to refer it to a separate section. In the tree (Figure 1) it is allied with a second winter-rainfall species, $M$. regalis (possibly misplaced here and without morphological support), plus all the eastern southern African (and summer rainfall area) species of subg. Vieusseuxia, which constitute a well supported $(1,87,60)$ lineage. It is biogeographically significant that these eastern species constitute a clade, thus representing a minor radiation of the genus in the region.

We segregate the remaining species of subg. Vieusseuxia (BP 98) in two sections based primarily on morphology. These are the small sect. Villosae, which includes the species clustered around $M$. villosa and which share outer tepal limbs as wide or wider than long and usually both leaves and stems pilose (not M. caeca). The remaining species fall by default in sect. Vieusseuxia: molecular analysis provides modest support for this alliance $(1,73,62$; excluding $M$. calcicola). The isolated position of $M$. algoensis (sister to sect. Vieusseuxia plus sect. Villosae ) and the position of $M$. barkerae in the $M$. villosa clade receive no morphological support and both are provisionally referred to sect. Vieusseuxia.

11. Subg. Homeria: this exclusively southern African alliance is well supported $(1,94,88)$ in the molecular analysis and is united morphologically by its hard, black corm tunic fibres and by specialized flowers in which the style branches and crests are reduced, the crests sometimes lacking, and the inner tepals are scarcely smaller than the outer (the Homeria-type flower sensu Goldblatt (1986c)). Both fugaceous and long-lived flowers are present in the subgenus. Basic chromosome number is $x=6$, but a few species have $n=5$ or 4 (and $2 n=9$ ). Leaf number is reduced in some species from several to consistently one leaf, evidently the derived condition. The inclusion of $M$. radians in the subg. Homeria clade (originally a separate genus Sessilistigma) is consistent with Goldblatt's (1991) reduction of the genus in Homeria. $M$. flexicaulis, originally assigned to a monotypic section of Moraea (Goldblatt 1982) is likewise retrieved within the subg. Homeria clade, which is consistent with its chromosome number and karyotype. We have no hesitation in including it in subg. Homeria. Its rather unusual morphology (the stem is strongly flexuose and the flowers have well developed style branches and crests) is somewhat anomalous for the subgenus, but recall the species pair $M$. knersvlaktensis and $M$. schlechteri (originally treated as Homeria sect. Namaquanae by Goldblatt (1981)) and we provisionally unite the three species in an enlarged sect. Flexuosae (the earliest name in Moraea for the section). There is no molecular support for the inclusion of $M$. louisabolusiae with these species as proposed by Goldblatt (1981, as $H$. bolusiae) based on morphology. We place $M$. louisabolusiae in sect. Homeria close to M. patens; a treatment consistent with both morphology and the molecular tree topology. Within the subgenus, the group of species around $M$. cookii also merits taxonomic recognition and we treat the alliance as sect. Stipantherae Goldblatt (1981). It then comprised five species with the single leaf clasping the stem for some distance, fugaceous flowers and, in four species, the filaments free distally. Of the five species M. britteniae and M. marlothii fall outside the clade and their continued inclusion in sect. Stipantherae must be viewed as provisional.

There is no molecular support for species groups based on flower shape, namely those with very short tepal claws clasping the base of the filament column (e.g. sect. Conantherae including Moraea bifida, $M$. miniata, $M$. pendula and several more) versus those 
with longer claws forming a wide, deep bowl (e.g. sect. Homeria, including M. collina, M. minor, M. ochroleuca, M. pyrophila and others). In fact, apart from three members of sect. Stipantherae and two of sect. Flexuosae, there are no significant species alliances retrieved in the molecular trees that merit taxonomic recognition and we fall back on the existing classification based on morphology in which two more sections were recognized (Goldblatt 1981): sects. Conantherae and Homeria as well as sect. Flexuosae and sect. Stipantherae. Separate molecular study of subg. Homeria using additional DNA sequences may help resolve relationships and provide a test for the current classification.

\section{CLASSIFACTION AND SYNOPSIS OF MORAEA}

Moraea Mill., Figures of Plants vol. 2: 159, t. 238 (1758) (as Morea), name and spelling conserved. Type also conserved: $M$. vegeta $\mathrm{L}$.

1. Subg. Plumariae Goldblatt \& J.C.Manning, subg. nov. Type species: M. lugubris (Salisb.) Goldblatt.

Plants with branched stems. Foliage leaves several, channelled. Flowers fugaceous, blue; tepals subequal but outer larger and with nectar guides, limbs laxly spreading; filaments united in lower half; style branches diverging at tips and stigmatic apically, crests plumose Capsules \pm globose. Basic chromosome number $x=10$.

\section{M. lugubris (Salisb.) Goldblatt}

2. Subg. Visciramosae Goldblatt in Annals of the Missouri Botanical Garden 63: 7 (1976b). Type species: M. bituminosa (L.f.) Ker Gawl.

Plants with branched stems, nodes sticky; corm tunics \pm woody, sticky on adaxial surface. Foliage leaves several or 2, channelled. Flowers fugaceous, variously coloured; tepals subequal or outer larger and with nectar guides, limbs reflexed; filaments united in lower half or free but contiguous; style branches broad with abaxial stigmatic lobe bearing a forked appendage in centre and well developed paired crests or style branches reduced, lacking crests, then flattened or filiform. Capsules \pm globose. Basic chromosome number $x=10$.

2a. Sect. Multifoliae Goldblatt \& J.C.Manning, sect. nov. Type species: $M$. vespertina Goldblatt \& J.C.Manning.

Foliage leaves several. Flowers white, pale blue or predominantly buff-brown; style branches and crests moderately or well developed.

\section{M. vespertina Goldblatt \& J.C.Manning 3. M. bubalina Goldblatt}

2b. Sect. Visciramosae Goldblatt \& J.C.Manning, sect. nov. Type species: M. bituminosa (L.f.) Ker Gawl.

Foliage leaves 2. Flowers yellow, blue or brown, occasionally white; style branches and crests moderately well developed or reduced and without crests (in M. simplex filiform and extending between the stamens).
4. M. bituminosa (L.f.) Ker Gawl.

5. M. inconspicua Goldblatt

6. M. viscaria (L.f.) Ker Gawl.

7. M. saldanhae Goldblatt \& J.C.Manning

8. M. elsiae Goldblatt

9. M. simplex Goldblatt \& J.C.Manning

3. Subg. Umbellatae Goldblatt \& J.C.Manning, subg. nov. Type: $M$. margaretae Goldblatt.

Rheome Goldblatt: 92 (1980a). Type species: $R$. maximiliani (Schltr.) Goldblatt (= Moraea maximiliani (Schltr.) Goldblatt).

Plants with branched stems, branches and leaves usually clustered at first aerial node; corm tunics dark brown, initially unbroken, later splitting irregularly. Foliage leaves several or solitary. Inflorescence spathes blunt or truncate, with outer spathe often diverging apically. Flowers fugaceous, pale yellow to \pm beige (rarely pale pink) with dark venation, sometimes with perianth tube; stamens united in lower half; style branches well developed or reduced and lacking crests (in $M$. nana with paired filiform arms extended horizontally). Capsules \pm club-shaped. Basic chromosome number $x=10$.
10. M. linderi Goldblatt
11. M. margaretae Goldblatt
12. M. intermedia Goldblatt \& J.C.Manning
13. M. cooperi Baker
14. M. longiflora Ker Gawl.
15. M. umbellata Thunb.
16. M. maximiliani (Schltr.) Goldblatt
17. M. nana (L.Bolus) Goldblatt

\section{Subg. Moraea}

Moraea rankless Corymbosae Baker: 10 (1896), nom. illegit. superfl. Type species: $M$. juncea $\mathrm{L}$. $=M$. vegeta L., type of the genus.

Plants with stems usually branched, sometimes repeatedly; corm tunics finely to coarsely fibrous or \pm woody. Foliage leaves several to 2(1). Flowers mostly yellow to buff-brown, occasionally pink to red, or partly white (blue in $M$. nubigena); filaments united in lower half; style branches and crests well developed (reduced in M. vlokii). Capsules \pm globose, exserted. Basic chromosome number $x=10$.

\section{4a. Sect. Moraea}

Corms often asymmetric; tunics of pale, coarse or fine fibres. Foliage leaves several to 2(1). Flowers yellow, sometimes pink to red or brown; filaments partially united; style branches and crests usually well developed (not M. vlokii).
18. M. vegeta L.
19. M. indecora Goldblatt
20. M. gawleri Spreng.
21. M. vlokii Goldblatt
22. M. namaquamontana Goldblatt

4b. Sect. Polyphyllae Goldblatt \& J.C.Manning, sect. nov. Type species: M. ramosissima (L.f.) Ker Gawl.

Plants usually multi-branched. Corm tunics brown, 
fragmenting irregularly. Foliage leaves several to many, broad and prominently channelled. Flowers yellow; filaments united in lower half or only at base; style branches and crests well developed.

23. M. ramosissima (L.f.) Druce

24. M. gariepensis Goldblatt

Uncertain position and provisionally placed here:

25. M. papilionacea (L.f.) Ker Gawl.

26. M. nubigena Goldblatt

5. Subg. Galaxia (Thunb.) Goldblatt \& J.C.Manning, stat. nov. Galaxia Thunb.: 50 (1782). Moraea sect. Galaxia (Thunb.) Goldblatt: 376 (1998). Type species: G. graminea Thunb., lecto. designated by Phillips (1951) = Moraea fugacissima (L.f.) Goldblatt.

Plants acaulescent at anthesis; corm tunics pale, usually finely fibrous. Leaves several, often plane and \pm prostrate, narrowly channelled or terete, hardly distinct from spathes. Flowers fugaceous, sessile, with solid perianth tube, yellow, white, or shades of pink to purple; tepals mostly without narrow claws (not M. kamiesmontana); style branches much reduced with crests obscure, stigma lobes entire or irregularly fringed. Capsules \pm globose. Basic chromosome number $x=9$.

5a. Series Unguiculatae Goldblatt \& J.C.Manning, ser. nov. Type species: M. kamiesmontana (Goldblatt) Goldblatt.

Flowers pink with white cup; tepals prominently clawed; filaments partly united; style branches with stigma lobes entire.

\section{M. kamiesmontana (Goldblatt) Goldblatt}

5b. Series Eurystigma (Goldblatt) Goldblatt in Novon 8: 377 (1998). Galaxia subg. Eurystigma Goldblatt: 398 (1979a,b). Galaxia ser. Eurystigma (Goldblatt) Goldblatt: 376 (1998). Type species: G. versicolor Salisb. ex Klatt (= Moraea versicolor (Salisb. ex Klatt) Goldblatt).

Flowers pink to purple or white (yellow in M. citrina); filaments largely united; style branches with stigma lobes entire.

28. M. citrina (G.J.Lewis) Goldblatt

29. M. barnardiella Goldblatt

30. M. melanops Goldblatt \& J.C. Manning

31. M. versicolor (Salisb. ex Klatt) Goldblatt

32. M. variabilis (G.J.Lewis) Goldblatt

33. M. minima Goldblatt

34. M. fenestralis (Goldblatt \& E.G.H.Oliver) Goldblatt

5c. Series Galaxia (Thunb.) Goldblatt in Novon 8: 376 (1998). Galaxia Thunb.: 50 (1782). Type species: as for subgenus.

Flower yellow or white, filaments largely united or spreading from base ( $M$. luteoalba); style branches with fringed stigma lobes.

\section{M. kamisensis Goldblatt}

36. M. luteoalba (Goldblatt) Goldblatt

37. M. galaxia (L.f.) Goldblatt \& J.C.Manning

38. M. pilifolia Goldblatt

39. M. vuvuzela J.C.Manning \& Goldblatt

40. M. albiflora (G.J.Lewis) Goldblatt

41. M. fugacissima (L.f.) Goldblatt

42. M. stagnalis (Goldblatt) Goldblatt

43. $M$. angulata Goldblatt

6. Subg. Monocephalae (Baker) Goldblatt in Annals of the Missouri Botanical Garden 63: 7 (1976b). Rankless Monocephalae Baker: 10 (1896). Type species: $M$. angusta (Thunb.) Ker Gawl., lecto. designated by Goldblatt: 7 (1976b).

Plants unbranched, usually with sticky nodes. Foliage leaf solitary, distally terete. Flowers fugaceous, yellow to buff-brown; stamens united only near base; style branches well developed; ovary sharply 3 -angular. Capsules ovoid-oblong. Seeds flattened and discoid. Basic chromosome number $x=10$.

\section{M. angusta (Thunb.) Ker Gawl. \\ 45. M. anomala G.J.Lewis \\ 46. $M$. neglecta G.J.Lewis \\ 47. M. vallisavium Goldblatt}

7. Subg. Acaules (Baker) Goldblatt \& J.C.Manning, stat. nov. Rankless Acaules Baker: 8 (1896) [as 'sect. Acaules Baker' (Goldblatt 1976b)]. Type species: M. ciliata (L.f.) Ker Gawl.

Plants usually acaulescent (not M. longipes), usually unbranched, often with single rhipidium; corm tunics usually pale and coarsely fibrous. Foliage leaves several to few, hardly distinct from spathes, channelled. Flowers fugaceous, retracted after anthesis to base of rhipidium, various colours; stamens united in lower half; style branches well developed. Capsules concealed in spathes. Basic chromosome number $x=10$.

48. M. falcifolia Klatt

49. M. ciliata (L.f.) Ker Gawl.

50. M. longipes Goldblatt \& J.C.Manning

51. M. tricolor Andrews

52. M. macronyx G.J.Lewis

8. Subg. Polyanthes (Goldblatt) Goldblatt \& J.C.Manning, comb. nov. Moraea sect. Polyanthes Goldblatt (1976b). Type species: M. polystachya (L.f.) Ker Gawl.

Corm tunics mostly of hard, black fibres. Foliage leaves several to solitary. Flowers fugaceous, mostly blue to mauve, also yellow or white; stamens united in lower half; ovary often included, style branches well developed with prominent crest or much reduced, sometimes as paired or single filiform arms. Capsules oblongellipsoid, sometimes beaked, exserted or included. Basic chromosome number $x=10$ but four sections have $x=6$.

8a. Sect. Serpentinae Goldblatt \& J.C.Manning, sect. nov. Type species: $M$. serpentina Baker.

Foliage leaves 2 or 3, twisted or coiled. Flowers blue, yellow or mostly white; style branches and crests well developed. Ovary and capsules included. 
53. M. serpentina Baker

54. $M$. tortilis Goldblatt

8b. Sect. Deserticola Goldblatt in Annals of the Missouri Botanical Garden 63: 7 (1976b). Type species: $M$. bolusii Baker.

Rankless Subracemosae Baker: 9 (1896) [as 'sect. Subracemosae Baker' in Goldblatt: 7 (1976b)]. Type species: $M$. edulis (L.f.) Ker Gawl. (= M. fugax (D.Delaroche) Ker Gawl.), lecto., designated by Goldblatt: 7 (1976b).

Barnardiella Goldblatt: 312 (1977a). Type species: B. spiralis (N.E.Br.) Goldblatt (= Moraea herrei (L.Bolus) Goldblatt).

Plants unbranched or branched, branches sometimes sessile. Foliage leaves solitary (sometimes 2 in M. fugax group). Flowers usually blue to mauve or violet (sometimes yellow or white); tepal claws short or \pm as long as limbs; stamens united in lower half; style branches well developed with erect crests or reduced, without crests (as paired or filiform arms extended horizontally in $M$. hexaglottis). Ovary and capsules included, sometimes beaked.
55. M. saxicola Goldblatt
56. M. macgregorii Goldblatt
57. M. namibensis Goldblatt
58. M. bolusii Baker
59. M. graniticola Goldblatt
60. M. herrei (L.Bolus) Goldblatt
61. $M$. rigidifolia Goldblatt
62. M. hexaglottis Goldblatt
63. M. fugax (D.Delaroche) Ker Gawl.
64. M. gracilenta Goldblatt
65. M. filicaulis Baker
66. M. macrocarpa Goldblatt

8c. Sect. Hexaglottis (Vent.) Goldblatt in Novon 8: 376 (1998). Hexaglottis Vent.: 6 (1808). Type species: H. longifolia (Jacq.) G.J.Lewis, lecto. designated by Lewis: $219(1959)=$ M. longifolia (Jacq.) Pers

Plantia Herbert: 89 (1844). Type species: P. flava Herb. (probably = Moraea virgata Jacq.).

Plants usually branched, secondary branches usually sessile. Flowers yellow, with tepals subequal with claws short; tepals united in tube in 2 species; style branches reduced to paired filiform arms extended either side of opposed stamen, ovary exserted or included and \pm sessile in species with perianth tube. Ovary and capsules exserted or included.

67. M. namaquana (Goldblatt) Goldblatt

68. M. lewisiae (Goldblatt) Goldblatt

69. M. longifolia (Jacq.) Pers.

70. M. riparia (Goldblatt) Goldblatt

71. M. brevituba (Goldblatt) Goldblatt

72. $M$. virgata Jacq.

8d. Sect. Gynandriris (Parl.) Goldblatt in Novon 8: 376 (1998). Gynandriris Parl.: 49 (1854). Iris subg. Gynandriris (Parl.) Baker: 2 (1892). Iris sect. Gynandriris (Parl.) Dykes: 229 (1913). Moraea sect. Gynandr- iris (Parl.) Goldblatt: 376 (1998). Type species: M. sisyrinchium (L.) Ker Gawl.

Helixyra Salisb. ex N.E.Br.: 348 (1929) [Helixyra Salisb., Trans. Hort. Soc. 1: 305 (1812), nom. nud.], nom. illeg. superf. pro Gynandriris. Type species: not indicated by author).

Moraea subg. Helixyra Salisb. ex Baker [as a combination but Helixyra Salisb. nom. inval.]: 48 (1892). Type species: M. simulans Baker, lecto., here designated.

Plants unbranched or few-branched; spathes translucent with dark veins. Flowers fugaceous, blue to purple or white; stamens united in lower half; style branches well developed with erect crests; ovary \pm sessile and with sterile tubular beak. Capsules with transparent walls, remaining enclosed in spathes.

73. M. australis Goldblatt

74. M. setifolia (L.f.) Druce

75. . cedarmontana (Goldblatt) Goldblatt

76. $M$. simulans Baker

77. M. sisyrinchium (L.) Ker Gawl.

78. M. mediterranea Goldblatt

79. M. pritzeliana Diels

80. $M$. contorta Goldblatt

81. M. hesperantha (Goldblatt) Goldblatt

8e. Sect. Polyanthes Goldblatt in Annals of the Missouri Botanical Garden 63: 8 (1976b). Type species: as for subgenus.

Plants few- to several-branched. Foliage leaves several to 2. Flowers shades of blue to violet or purple (rarely yellow); style branches well developed with prominent crests or reduced and crests vestigial. Ovary and capsules usually exserted.

82. M. bipartita L.Bolus

83. M. polystachya (L.f.) Ker Gawl.

84. $M$. venenata Dinter

85. M. speciosa (L.Bolus) Goldblatt

86. M. polyanthos Thunb.

87. M. deserticola Goldblatt

88. M. tanquana Goldblatt \& J.C.Manning

89. M. carsonii Baker

8f. Sect. Pseudospicatae Goldblatt \& J.C.Manning, sect. nov. Type species: M. pseudospicata Goldblatt.

Roggeveldia Goldblatt: 840 (1979c publ. 1980). Type species: R. fistulosa Goldblatt (= Moraea fistulosa (Goldblatt) Goldblatt).

Plants unbranched or branched, secondary branches sometimes sessile. Foliage leaves solitary ( 2 in M. callista, which may be misplaced here). Flowers usually blue to mauve or violet; tepal claws short or \pm as long as limbs; stamens united in lower half; style branches well developed with erect crests or reduced, without crests, sometimes as paired or single filiform arms extended horizontally. Ovary and capsules exserted or included.

90. M. elliotii Baker

91. M. exiliflora Goldblatt

92. M. alpina Goldblatt 
93. M. stricta Baker

94. M. thomsonii Baker

95. M. natalensis Baker

96. M. inclinata Goldblatt

97. M. iringensis Goldblatt

98. M. afro-orientale Goldblatt

99. M. callista Goldblatt

100. M. crispa Thunb.

101. $M$. verecunda Goldblatt

102. M. pseudospicata Goldblatt

103. M. pearsonii Goldblatt \& J.C.Manning

104. M. monticola Goldblatt

105. M. marginata J.C.Manning \& Goldblatt

106. $M$. fistulosa (Goldblatt) Goldblatt

9. Subg. Grandiflorae Goldblatt in Annals of the Missouri Botanical Garden 63: 8 (1976b). Type species: M. spathulata (L.f.) Klatt.

Hymenostigma Hochst. in Flora 27: 24 (1844). Type species: H. schimperi Hochst. (= Moraea schimperi (Hochst.) Pic.-Serm.)

Iridopsis Welw. ex Baker in Transactions of the Linnean Society of London, Botany 1: 270 (1878), pro syn.

Plants unbranched. Flowers yellow (white) or blue to violet; stamens united in lower half; ovary usually 3-angled; style branches well developed with prominent crests. Capsules large, exserted. Seeds flattened, discoid. Basic chromosome number $x=6$.

107. M. spathulata (L.f.) Klatt

108. M. moggii N.E.Br.

109. M. huttonii (Baker) Oberm.

110. M. alticola Goldblatt

111. $M$. reticulata Goldblatt

112. M. robusta (Goldblatt) Goldblatt

113. M. galpinii Baker) N.E.Br.

114. M. muddii N.E.Br.

115. $M$. ardesiaca Goldblatt

116. M. carnea Goldblatt

117. M. graminicola Oberm.

118. M. hiemalis Goldblatt

119. M. unibracteata Goldblatt

120. M. bella Harms

121. M. macrantha Baker

122. M. textilis Baker

123. M. ventricosa Baker

124. M. schimperi (Hochst.) Pic. Serm.

125. M. verdickii De Wild.

126. M. tanzanica Goldblatt

127. M. brevifolia Goldblatt

128. $M$. inyangani Goldblatt

129. M. angolensis Goldblatt

130. M. upembana Goldblatt

131. M. clavata Goldblatt

132. M. bovonei R.C.Foster

133. M. balundana Chiov.

134. M. unifoliata Goldblatt

10. Subg. Vieusseuxia (D.Delaroche) Baker, Handbook of the Irideae: 48 (1892). Vieusseuxia D.Delaroche: 31 (1766). Type species: V. spiralis D.Delaroche, lectotype designated by Goldblatt: 8 $(1976 b)=M$. bellendenii (Sweet) N.E.Br.
Phaianthes Raf.: 30 (1836). Type species: P. lurida (Ker Gawl.) Raf. (= Moraea lurida Ker Gawl.).

Plants simple or few-branched; corm tunics of brown firm to soft fibres. Foliage leaf solitary (several in Moraea fergusioniae), sometimes villous abaxially. Flowers long-lived, variously coloured, usually with inner tepals 3-lobed with prominent central cusp or reduced to simple, hair-like cusps or absent (entire in a few species); stamens united in lower half or entirely, or united at base, rarely free or virtually so; style branches usually well developed with erect crests (reduced and crests vestigial in $M$. worcesterensis). Capsules ovoidellipsoid, usually exserted. Basic chromosome number $x$ $=6$.

10a. Sect. Integres Goldblatt \& J.C.Manning, sect. nov. [Sect. Thomasiae Goldblatt in Annals of Kirstenbosch Botanic Garden 14: 138 (1986), invalid name]. Type species: $M$. thomasiae Goldblatt.

Plants often unbranched. Foliage leaf solitary. Flowers yellow, inner tepals spathulate, entire; filaments free or barely united at base.

\section{M. thomasiae Goldblatt}

10b. Sect. Vieusseuxia (D.Delaroche) Goldblatt \& J.C.Manning, comb. nov. Vieusseuxia D.Delaroche: 31 (1766). Type species: as for subgenus.

Plants branched or not. Foliage leaf usually solitary (not M. fergusoniae). Flowers mostly blue to violet, pink, purple, white, rarely yellow; inner tepals often tricuspidate, hair-like, sometimes absent; filaments usually united in lower half, occasionally free or barely united at base.

136. M. incurva G.J.Lewis

137. M. barkerae Goldblatt

138. M. lurida Ker Gawl.

139. M. cantharophila Goldblatt \& J.C.Manning

140. $M$. insolens Goldblatt

141. M. worcesterensis Goldblatt

142. $M$. fergusoniae L.Bolus

143. M. unguiculata Ker Gawl.

144. M. rivulicola Goldblatt \& J.C.Manning

145. M. algoensis Goldblatt

146. M. longiaristata Goldblatt

147. $M$. barnardii L.Bolus

148. M. debilis Goldblatt

149. M. lilacina Goldblatt \& J.C.Manning

150. $M$. regalis Goldblatt

151. M. tricuspidata Goldblatt

152. M. deltoidea Goldblatt \& J.C.Manning

153. $M$. bellendenii Ker Gawl.

154. M. trifida R.C.Foster

155. M. marionae Baker

156. M. dracomontana Goldblatt

157. M. modesta Killick

158. M. pubiflora N.E.Br.

159. M. brevistyla (Goldblatt) Goldblatt

160. M. vigilans Goldblatt \& J.C.Manning

161. M. albicuspa Goldblatt

162. M. decipiens Goldblatt \& J.C.Manning

163. M. helmei Goldblatt \& J.C.Manning 
164. M. mutila (C.H.Bergius ex Eckl.) Goldblatt \& J.C.Manning

165. M. cuspidata Goldblatt \& J.C.Manning

166. M. tripetala (L.f.) Ker Gawl.

167. M. ogamana Goldblatt \& J.C.Manning

168. M. hainebachiana Goldblatt \& J.C.Manning

169. M. amabilis Diels

170. M. grandis Goldblatt \& J.C.Manning

10c. Sect. Villosae Goldblatt \& J.C.Manning, sect. nov. Type species: M. villosa (Ker Gawl.) Ker Gawl.

Foliage leaf and stem usually pilose or velvety abaxially (not M. caeca). Flowers variously coloured, large with outer tepal limbs exceeding claws, limbs rotund, as wide as or wider than long; inner tepals tricuspidate with central cusp long and trailing.

171. M. aristata (D.Delaroche) Asch. \& Graeb.

172. M. caeca Goldblatt

173. M. amissa Goldblatt

174. M. atropunctata Goldblatt

175. M. tulbaghensis L.Bolus

176. M. villosa (Ker Gawl.) Ker Gawl.

177. M. calcicola Goldblatt

178. M. loubseri Goldblatt

179. M. gigandra L.Bolus

11. Subg. Homeria (Vent.) Goldblatt \& J.C.Manning, comb. et stat. nov. Homeria Vent.: 2 (1808). Type species: H. collina (Thunb.) Salisb. (= M. collina Thunb).

Sessilistigma Goldblatt: 156 (1984b). Type species: $S$. radians Goldblatt (= Moraea radians (Goldblatt) Goldblatt).

Plants simple or few-branched; corm tunics of wiry, black fibres. Foliage leaves few to solitary. Flowers fugaceous or long-lived, yellow, beige or pink to orange, sometimes with dark markings; outer and inner tepals subequal, both whorls usually with nectar guides, claws as long as limbs or much shorter; stamens with filaments united entirely or free near apices (free in $M$. radians); style branches reduced with crests vestigial or absent. Capsules ovoid-ellipsoid to cylindric, included or exserted. Basic chromosome number $x=6$.

11a. Sect. Stipanthera (Goldblatt) Goldblatt \& J.C.Manning, comb. nov. Homeria sect. Stipantherae Goldblatt ['Stipanthera'] in Annals of the Missouri Botanical Garden 68: 426 (1981). Type species: M. pallida Baker.

Leaf solitary, clasping stem below. Flowers yellow (rarely pink); tepals with claws much shorter than limbs, clasping or forming a cup including base of filament column; stamens with filaments free near apices or fully united.
180. M. cookii L.Bolus
181. M. pallida Baker
182. M. marlothii L.Bolus
183. M. reflexa Goldblatt
184. M. britteniae (L.Bolus) Goldblatt

11b. Sect. Flexuosae Goldblatt in Annals of the Missouri Botanical Garden 69: 356 (1983, as 1982). Type species: M. flexuosa Goldblatt (= M. flexicaulis Goldblatt).

Homeria sect. Namaquanae Goldblatt ['Namaquana']: 425 (1981). Type species: H. schlechteri L. Bolus.

Leaves several, decreasing in size above. Flowers fugaceous, yellow; tepals with claws much shorter than limbs, clasping or forming a cup including base of filament column; stamens with filaments free near apices or \pm fully united.

185. M. schlechteri (L.Bolus) Goldblatt

186. M. knersvlaktensis Goldblatt

187. M. flexicaulis Goldblatt

11b. Sect. Homeria (Vent.) Goldblatt in Novon 8: 374 (1998). Type species: H. collina (Thunb.) Salisb. (= M. collina Thunb).

Stem straight or flexed. Foliage leaves several to one. Flowers fugaceous or lasting two days; tepal claws short and erect or long and forming a cup enclosing stamens; filaments usually united entirely (free in $M$. radians).
188. M. cedarmonticola Goldblatt
189. M. autumnalis (Goldblatt) Goldblatt
190. M. ochroleuca (Salisb.) Drapiez
191. M. flaccida Sweet
192. M. collina Thunb.
193. M. pyrophila Goldblatt
194. M. minor Eckl.
195. M. longistyla (Goldblatt) Goldblatt
196. M. comptonii (L.Bolus) Goldblatt
197. M. elegans Jacq.
198. $M$. radians (Goldblatt) Goldblatt
199. M. bulbillifera (G.J.Lewis) Goldblatt
200. M. serratostyla (Goldblatt) Goldblatt
201. M. patens (Goldblatt) Goldblatt
202. M. louisabolusiae Goldblatt
203. M. vallisbelli (Goldblatt) Goldblatt
204. M. flavescens (Goldblatt) Goldblatt
205. M. demissa Goldblatt

11c. Sect. Conantherae (Goldblatt) Goldblatt \& J.C.Manning, comb. nov. Homeria sect. Conantherae Goldblatt ['Conanthera']: 427 (1981). Type species: Homeria miniata (Andrews) Sweet $(=M$. miniata Andrews).

Stem straight or flexed. Foliage leaves several to one. Flowers fugaceous, members of both whorls well developed and bearing nectar guides; tepal claws short, erect, forming a cup enclosing base of filaments; filaments united entirely; anthers parallel with stigmatic surfaces emerging between anthers.

206. M. aspera Goldblatt

207. M. miniata Andrews

208. M. pendula (Goldblatt) Goldblatt

209. M. karooica Goldblatt

210. M. fenestrata Goldblatt

211. M. bifida (L.Bolus) Goldblatt

212. $M$. fragrans Goldblatt

213. M. fuscomontana (Goldblatt) Goldblatt

214. M. brachygyne (Schltr.) Goldblatt 


\section{ACKNOWLEDGEMENTS}

We owe profuse thanks to Roy Gereau, Missouri Botanical Garden, for reviewing the manuscript and proffering corrections to the complex infrageneric nomenclature. Anthony Magee kindly assisted with the figures. JS was supported by the funding programme 'LOEWE-Landes-Offensive zur Entwicklung Wissenschaftlich-ökonomischer Exzellenz' from the Ministry of Higher Education, Research, and the Arts, Hesse, Germany.

\section{REFERENCES}

BAKER, J.G. 1878. Iridopsis. Transactions of the Linnaean Society of London, Botany 1: 270.

BAKER, J.G. 1892. Handbook of the Irideae. George Bell and Co., London.

BAKER, J.G. 1896. Irideae. In W.T. Thiselton-Dyer (editor), Flora capensis 6: 6-171. Reeve \& Co, London.

BROWN, N.E. 1929. Contributions to a knowledge of the Transvaal Iridaceae. Part I. Transactions of the Royal Society of South Africa 17: $341-352$.

DYKES, W.R. 1913. The genus Iris. Dover, New York.

DELAROCHE, D. 1766. Descriptiones Plantarum Aliqout Novarum. Verbeek, Leiden.

GOLDBLATT, P. 1973. Contributions to the knowledge of Moraea (Iridaceae) in the summer rainfall region of South Africa. Annals of the Missouri Botanical Garden 60: 204-259.

GOLDBLATT, P. 1976a. The genus Moraea in the winter-rainfall region of southern Africa. Annals of the Missouri Botanical Garden 63: 63: $657-786$

GOLDBLATT, P. 1976b. Evolution, cytology and subgeneric classification in Moraea (Iridaceae). Annals of the Missouri Botanical Garden 63: 1-23.

GOLDBLATT, P. 1977a. Barnardiella: A new genus of the Iridaceae and its relationship to Gynandriris and Moraea. Annals of the Missouri Botanical Garden 63: 309-313.

GOLDBLATT, P. 1977b. Systematics of Moraea (Iridaceae) in tropical Africa. Annals of the Missouri Botanical Garden 64: 243-295.

GOLDBLATT, P. 1979a. Chromosome cytology and karyotype change in Galaxia (Iridaceae). Plant Systematics and Evolution 133: 61-69.

GOLDBLATT, P. 1979b. Biology and systematics of Galaxia (Iridaceae). Journal of South African Botany 45: 385-423.

GOLDBLATT, P. 1979c. Roggeveldia, a new genus of southern African Iridaceae-Irideae. Annals of the Missouri Botanical Garden 66 : 839-844.

GOLDBLATT, P. 1980a. Redefinition of Homeria (Iridaceae) in the light of biosystematic data, with Rheome gen. nov. Botaniska Notiser 133: 85-95.

GOLDBLATT, P. 1980b. Systematics of Gynandriris (Iridaceae), a Mediterranean-southern African disjunct. Botaniska Notiser 133: 239-260.

GOLDBLATT, P. 1981. Systematics and biology of Homeria (Iridaceae). Annals of the Missouri Botanical Garden 68: 413-503.

GOLDBLATT, P. 1982. A synopsis of Moraea (Iridaceae) with new taxa, transfers and notes. Annals of the Missouri Botanical Garden 69: 351-369.

GOLDBLATT, P. 1984a. New species of Galaxia (Iridaceae) and notes on cytology and evolution in the genus. Annals of the Missouri Botanical Garden 71: 1082-1087.

GOLDBLATT, P. 1984b. Sessilistigma, a new genus of Iridaceae-Iridoideae from the southwestern Cape. Journal of South African Botany 50: 149-157.

GOLDBLATT, P. 1986a. The genus Moraea in southern Africa. Annals of the Kirstenbosch Botanical Garden 14. National Botanical Garden and Missouri Botanical Garden.

GOLDBLATT, P. 1986b. Cytology and systematics of the Moraea fugax complex (Iridaceae). Annals of the Missouri Botanical Garden 73: 140-157.

GOLDBLATT, P. 1986c. Convergent evolution of the Homeria flower type in six new species of Moraea (Iridaceae) in southern Africa. Annals of the Missouri Botanical Garden 73: 102-116.

GOLDBLATT, P. 1987. Systematics of the southern African genus
Hexaglottis (Iridaceae-Iridoideae). Annals of the Missouri Botanical Garden 74: 542-569.

GOLDBLATT, P. 1991. An overview of the systematics, phylogeny and biology of the southern African Iridaceae. Contributions from the Bolus Herbarium 13: 1-74.

GOLDBLATT, P. 1998. Reduction of Barnardiella, Galaxia, Gynandriris, Hexaglottis, Homeria and Roggeveldia in Moraea (Iridaceae: Irideae). Novon 8: 371-377.

GOLDBLATT, P. \& MANNING, J.C. 2009. New species of Moraea (Iridaceae: Iridoideae), with range extensions and miscellaneous notes for southern African species. Bothalia 39: 1-10.

GOLDBLATT, P. \& MANNING, J.M. 2013. Review of chromosome cytology in Moraea (Iridaceae: Irideae): what chromosomes reveal about the evolution of the genus. Bothalia 43: 43-54.

GOLDBLATT, P., RODRIGUEZ, A., POWELL, M.P., JONATHAN DAVIES, T., MANNING, J.C., VAN DER BANK, M. \& SAVOLAINEN, V. 2008. Iridaceae 'Out of Australasia'? Phylogeny, biogeography, and divergence time based on plastid DNA sequences. Systematic Botany 33,3: 495-508.

GOLDBLATT, P., SAVOLAINEN, V., PORTEOUS, O., SOSTARIC, I., POWELL, M., REEVES, G., MANNING, J.C., BARRACLOUGH, T.G. \& CHASE, M.W. 2002. Radiation in the Cape flora and the phylogeny of peacock irises Moraea (Iridaceae) based on four plastid DNA regions. Molecular Phylogenetics and Evolution 25: 341-360

HERBERT, W. 1844. Miscellaneous matter. Edwards's Botanical Register 30: 89

HOCHSTETTER, C.F.F. 1844. Hymenostygma. Flora 27: 24

HUELSENBECK, J.P. \& RONQUIST, F. 2001. MrBayes: Bayesian inference of phylogenetic trees. Bioinformatics 17: 754, 755.

LEWIS, G.J. 1959. South African Iridaceae. A revision of Hexaglottis. Journal of South African Botany 25: 215-230.

LEWIS, P.O. 2001. A likelihood approach to estimating phylogeny from discrete morphological character data. Systematic Biology 50: 913-925.

MILLER, P. 1758. Morea. Figures of the most beautiful, useful and uncommon plants described in The Gardener's Dictionary: 159, t. 238.

MÜLLER, K. 2005. SeqState-primer design and sequence statistics for phylogenetic DNA datasets. Applied Bioinformatics 4: 65-69.

NYLANDER, J.A.A. 2004. MrModeltest v.2. In program distributed by the author, Evolutionary Biology Centre, Uppsala University.

PARLATORE, F. 1854. Nuovi generi et nuovi specie di piante monocotyledoni. Le Monnier, Florence.

PHILLIPS, E.P. 1951. The genera of South African flowering plants. $2^{\text {nd }}$ edn. Memoirs of the botanical survey of South Africa No. 25. Dept. of Agriculture, Pretoria.

RAFINESQUE, C. 1836. Flora Telluriana 4. Published by author, Philadelphia.

SCHNITZLER, J., T. G. BARRACLOUGH, T.G., BOATWRIGHT, J.S., MANNING, J.C., GOLDBLATT, P., POWELL, M.P, REBELO, T. \& SAVOLAINEN, V. 2011. Causes of plant diversification in the Cape biodiversity hotspot of South Africa. Systematic Biology 60: 343-357.

SIMMONS, M.P. \& OCHOTERENA, H. 2000. Gap characters in sequence-based phylogenetic analyses. Systematic Biology, 49: 369-381.

STAMATAKIS, A. 2006. RAxML-VI-HPC: Maximum likelihoodbased phylogenetic analyses with thousands of taxa and mixed models. Bioinformatics 22: 2688-2690.

STAMATAKIS, A., HOOVER, P. \& ROUGEMONT, J. 2008. A rapid bootstrap algorithm for the RAxML web servers. Systematic Biology 57: 758-771.

SWOFFORD, D.L. 2002. PAUP* Phylogenetic Analysis Using Parsimony (*and other methods) v. 4.0b10. Sinauer Associates, Sunderland, Massachusetts.

THUNBERG, .P. 1782. Nova genera plantarum. Edman, Uppsala.

VENTENAT, E.P. 1808. Decas generum novorum aut parum cognitarum. E. Dufarb, Paris. 